\title{
Current status of pharmacokinetic and safety studies of multidrug-resistant tuberculosis treatment in children
}

\author{
A. J. Garcia-Prats, * E. M. Svensson, ${ }^{\dagger \neq}$ E. D. Weld,§ H. S. Schaaf,* A. C. Hesseling* \\ *Desmond Tutu TB Centre, Department of Paediatrics and Child Health, Faculty of Medicine and Health Sciences, \\ Stellenbosch University, Cape Town, South Africa; 'Department of Pharmacy, Radboud University Medical Center, \\ Nijmegen, The Netherlands; 'Department of Pharmaceutical Biosciences, Uppsala University, Uppsala, Sweden; \\ §Department of Medicine, Divisions of Clinical Pharmacology \& Infectious Disease, The Johns Hopkins University \\ School of Medicine, Baltimore, Maryland, USA
}

S U M M A RY

\begin{abstract}
After decades of neglect, data are finally becoming available on the appropriate, safe dosing of key secondline anti-tuberculosis drugs used for treating multidrugresistant tuberculosis (MDR-TB) in children, including levofloxacin (LVX), moxifloxacin (MFX), linezolid (LZD) and delamanid (DLM). Much needed data on some novel and repurposed drugs are still lacking, including for bedaquiline (BDQ), pretomanid (PTM) and clofazimine (CFZ). We review the status of pharmacokinetic (PK) and safety studies of key anti-tuberculosis medications in children with MDR-TB, identify priority knowledge gaps and note ongoing work to address those gaps, in the context of planning for an efficacy trial in children with MDR-TB. There is international consensus
\end{abstract}

that an efficacy trial of a novel, all-oral, shortened MDRTB treatment trial in children is both needed and feasible. Key novel and repurposed second-line anti-tuberculosis drugs include BDQ, DLM, PTM, MFX, LVX, CFZ and LZD. The rapidly emerging PK and safety data on these medications in children with MDR-TB from studies that are underway, completed or planned, will be critical in supporting such an efficacy trial. Commitment to addressing the remaining knowledge gaps, developing child-friendly formulations of key medications, improving the design of paediatric PK and safety studies, and development of international trial capacity in children with MDR-TB are important priorities.

KEY WORDS: MDR-TB; children; PK; trials; safety
CHILDREN REPRESENT a substantial proportion of the global burden of multidrug-resistant tuberculosis (MDR-TB), defined as TB resistant to at least both isoniazid and rifampicin, with an estimated 25000 32000 incident cases globally each year. ${ }^{1,2}$ Recent years have seen a rapidly evolving research landscape for MDR-TB treatment in adults, which has included the development and conditional registration of multiple novel anti-tuberculosis medications, the increased use of repurposed medications and the evaluation of shorter, better-tolerated regimens. Children also stand to benefit substantially from these advances in treatment strategies for MDR-TB; however, there have been delays in evaluating these new and repurposed medications in paediatric studies.

Understanding the pharmacokinetics (PK) and safety of anti-tuberculosis medications in children, and ensuring the availability of child-friendly formulations, are critically important to providing access to safe and effective treatment of MDR-TB in human immunodeficiency virus (HIV) infected and noninfected children. Furthermore, there is international consensus that an efficacy trial of a shortened, all-oral regimen is needed in children with MDR-TB. ${ }^{3}$ An understanding of optimal, safe doses of medications to be included in Phase III trial regimens is critically important. We highlight here the status of PK and safety studies of key novel and repurposed second-line anti-tuberculosis medications in children with MDR$\mathrm{TB}$, including bedaquiline (BDQ), delamanid (DLM), pretomanid (PTM), moxifloxacin (MFX), levofloxacin (LVX), clofazimine (CFZ) and linezolid (LZD), and identifying priority knowledge gaps and ongoing work to address those gaps, in the context of planning for an efficacy trial in children with MDR-TB.

\section{APPROACH TO DESIGN OF TRIALS OF THE PHARMACOKINETICS AND SAFETY OF ANTI- TUBERCULOSIS DRUGS IN CHILDREN}

Well-designed and executed paediatric PK and safety studies are central to anti-tuberculosis drug development in children. The first step in the currently accepted approach to determining the types of studies

Correspondence to: Anthony J Garcia-Prats, Desmond Tutu TB Centre, Department of Paediatrics and Child Health, Faculty of Medicine and Health Sciences, Stellenbosch University, P O Box 241, Cape Town 8000, South Africa. e-mail: garciaprats@sun.ac.za

Article submitted 23 May 2017. Final version accepted 3 August 2017. 
required for drug development in children is to assess whether it is reasonable to extrapolate a drug's efficacy from adult trials to children. ${ }^{4}$ This depends on whether, compared to adults, children could reasonably be expected to have a similar disease progression and a similar relationship between drug exposure and response to the relevant treatment. ${ }^{4}$ In the case of $\mathrm{TB}$, the consensus has been that children would be expected to have at least as good a response to treatment as adults, given the paucibacillary nature of TB disease in children. ${ }^{5,6}$ The priority then for paediatric trials of anti-tuberculosis drugs is to perform PK studies to identify the doses in children that result in exposures approximating those in adults receiving the recommended dose, and to establish safety in children at those doses. 5,6

Although common in routine clinical practice, paediatric drug doses cannot reliably be directly extrapolated from the $\mathrm{mg} / \mathrm{kg}$ of body weight dose in adults. This is because of both size-related and agerelated differences in PK. Size-related changes can be described using allometry, which is the study of how biological processes, volumes, body parts or organs scale with body size. ${ }^{7}$ Many biological processes, including clearance, which is a primary driver of drug exposure, scale with body size at a less-thanproportional rate, with the generally accepted 3/4 allometric scaling approach. ${ }^{8}$ The linear extrapolation of $\mathrm{mg} / \mathrm{kg}$ doses from adults to children therefore results in lower drug exposures in children, with the worst underexposure in the smallest children. Like many other body volumes, volume of distribution, also a key driver of drug exposures, scales more proportionally with body size, although body composition differences alter this in the smallest infants. ${ }^{8}$

In addition to considerations of size, age-related factors also affect anti-tuberculosis drug PK in children. ${ }^{9}$ Most biological processes, many of which have an important influence on drug disposition, continue to mature and develop after birth. This includes, but is not limited to, changes in gastrointestinal function and gastric $\mathrm{pH}$, changes in renal function, alterations in body composition, such as proportion of body fat and body water, and development of the capacity of enzymes responsible for drug metabolism. ${ }^{9}$ The most dramatic changes occur in the first weeks and months of life, and most processes have reached near or full maturity by 2 years of age.

To establish the appropriate paediatric doses of TB medications, carefully designed trials are thus needed that include children across all relevant age groups, with a particular focus on children aged $<2$ years, where the influence of size and age on PK is most pronounced. Given the potential for drug-drug interactions, it is also critically important that HIVinfected children are included in these studies.

\section{CONSIDERATIONS FOR ASSESSING SAFETY IN CHILDREN}

Adverse effects of anti-tuberculosis drugs are often reported to be less common in children than in adults. ${ }^{10,11}$ Although this observation may be correct, it may be at least partly due to lower drug exposures at the same $\mathrm{mg} / \mathrm{kg}$ bodyweight doses in children than in adults, as has been shown with the fluoroquinolones (FQs). ${ }^{12-14}$ Also complicating interpretation of this is the distinct lack of prospective studies accurately documenting adverse effects in children. Due to the difficulty in assessment in children, some adverse effects may be under-recognised, especially those based on subjective report such as peripheral neuropathy, pain and vision impairment, or those requiring specialised testing such as hearing loss. The majority of reported adverse effects in children are mild or moderate and of little clinical importance. However, these may still be unacceptable to children or care givers/parents, leading to social stigmatisation (e.g., skin discolouration with CFZ) or non-adherence to medication (e.g., due to nausea and vomiting), which may negatively impact treatment outcomes.

Data in juvenile animal studies and from trials in adults should provide some additional insight into anticipated adverse effects in children. It is tempting to assume that adverse effect profiles in children are similar to those in adults, given similar drug exposures. Although they may be, this assumption must be carefully tested in paediatric studies. ${ }^{15,16}$ Adverse effects seen in juvenile animal models or in adults may not be seen in children at clinically relevant doses, although such medications may be perceived as poor candidates for paediatric treatment. A relevant example is the persistent reluctance to use FQs in children with MDR-TB in some settings due to the arthropathy seen in juvenile animals, ${ }^{17}$ although several human studies have documented the safety of long-term FQ use in children. ${ }^{12,18}$ On the other hand, children as developing organisms with developing systems may be at risk for a spectrum or severity of adverse effects not seen in adults. The classic example is chloramphenicol, which was effectively and safely used widely in adults with penicillin-resistant infections, but caused 'gray-baby syndrome' in infants due to the immaturity of the hepatic uridine $5^{\prime}$-diphospho-glucuronyl transferase enzymes in children, which hampered metabolism of the drug. ${ }^{19}$ The safety of new medications or repurposed medications with new doses must be carefully evaluated, particularly in young children.

Monitoring safety in studies of MDR-TB treatment has its own inherent challenges. Given that these multidrug regimens include as many as 5-7 different medications, with potentially overlapping adverse effects, assessing the attribution of individual drugs for certain adverse effects is challenging. This may be 
Table 1 Status of PK and safety data on novel anti-tuberculosis medications in children and ongoing or planned paediatric studies

\begin{tabular}{|c|c|c|c|}
\hline & Current data in children & Key knowledge gaps & Ongoing or planned studies \\
\hline \multicolumn{4}{|l|}{$\mathrm{BDQ}$} \\
\hline PK & No data in children & $\begin{array}{l}\text { Data on PK and optimal paediatric } \\
\text { doses in all ages }\end{array}$ & \multirow{3}{*}{$\begin{array}{l}\text { Janssen C211: BDQ PK and safety in } \\
\text { non-HIV-infected children with } \\
\text { MDR-TB aged 0-17 years }(n=60) \\
\text { IMPAACT P1108: BDQ PK and safety in } \\
\text { HIV-infected and non-infected } \\
\text { children with MDR-TB aged } 0-17 \\
\text { years }(n=72) ; \text { includes HIV-infected } \\
\text { children on selected ARVs }\end{array}$} \\
\hline Safety & No data in children & $\begin{array}{l}\text { Data on safety at paediatric doses } \\
\text { in all ages }\end{array}$ & \\
\hline $\begin{array}{l}\text { Drug-drug } \\
\text { interactions }\end{array}$ & $\begin{array}{l}\text { Important interactions with ARVs } \\
\text { expected; no data in children }\end{array}$ & $\begin{array}{l}\text { Data on interactions with ARVs in } \\
\text { HIV-infected children }\end{array}$ & \\
\hline \multicolumn{4}{|l|}{ DLM } \\
\hline PK & $\begin{array}{l}\text { Data on PK in non-HIV-infected } \\
\text { children aged } 6-17 \text { years }(n=13) \text {; } \\
\text { drug exposure in children within } \\
\text { adult range }\end{array}$ & $\begin{array}{l}\text { Data on PK and optimal doses in } \\
\text { children aged }<6 \text { years; potential } \\
\text { for once daily dosing (twice daily } \\
\text { dosing being studied) }\end{array}$ & \multirow{3}{*}{$\begin{array}{l}\text { Otsuka 232/233: DLM PK and safety in } \\
\text { children with MDR-TB aged 0-17 } \\
\text { years }(n=36) \\
\text { IMPAACT 2005: DLM PK and safety in } \\
\text { HIV-infected and non-infected } \\
\text { children with MDR-TB aged 0-17 } \\
\text { years }(n=36-48)\end{array}$} \\
\hline Safety & $\begin{array}{l}\text { Data on safety in non-HIV-infected } \\
\text { children aged 6-17 years }(n=13) \\
\text { safe with minimal QT prolongation }\end{array}$ & $\begin{array}{l}\text { Data on safety at paediatric doses } \\
\text { in children aged }<6 \text { years }\end{array}$ & \\
\hline $\begin{array}{l}\text { Drug-drug } \\
\text { interactions }\end{array}$ & $\begin{array}{l}\text { Important interactions with ARVs not } \\
\text { expected; no data in children }\end{array}$ & $\begin{array}{l}\text { Data on interactions with ARVs in } \\
\text { HIV-infected children }\end{array}$ & \\
\hline \multicolumn{4}{|l|}{ Pretomanid } \\
\hline PK & No data in children & $\begin{array}{l}\text { Data on PK and optimal paediatric } \\
\text { doses in all ages }\end{array}$ & \multirow[t]{3}{*}{ None } \\
\hline Safety & No data in children & $\begin{array}{l}\text { Data on safety at paediatric doses } \\
\text { in all ages }\end{array}$ & \\
\hline $\begin{array}{l}\text { Drug-drug } \\
\text { interactions }\end{array}$ & $\begin{array}{l}\text { Important interactions with some ARVs } \\
\text { expected; no data in children }\end{array}$ & $\begin{array}{l}\text { Data on interactions with ARVs in } \\
\text { HIV-infected children }\end{array}$ & \\
\hline
\end{tabular}

$\mathrm{PK}=$ pharmacokinetic; $\mathrm{BDQ}=$ bedaquiline; HIV = human immunodeficiency virus; MDR-TB = multidrug-resistant tuberculosis; ARV = antiretroviral; IMPAACT = International Maternal Pediatric Adolescent AIDS Clinical Trials; DLM = delamanid.

more challenging in HIV-infected children who will also be taking antiretrovirals. Even where the adverse effects of individual drugs are described, it may be difficult to predict whether there will be an additive risk of adverse effects where there is overlap. QT interval prolongation, a known adverse effect of BDQ, DLM, CFZ, and the FQs, is such an example. For repurposed medications for which there may be some paediatric experience, such as for LZD, the long duration of treatment for TB may result in a different risk of adverse effects compared to short-term treatment of non-tuberculosis infections. Particularly for the novel medications, the number of adults or children who have ever been treated with these medications remains small. An efficacy trial enrolling a large number of children would therefore need to carefully monitor for previously unreported adverse effects.

The adverse effects of the priority anti-tuberculosis medications listed above have been described in detail elsewhere; ${ }^{12}$ key safety considerations and knowledge gaps are shown in Tables 1 and 2 .

\section{DEVELOPMENTS IN PHARMACOKINETIC TRIAL DESIGN IN CHILDREN WITH TUBERCULOSIS}

The study of the PK of anti-tuberculosis drugs in children has historically often been through observational studies, with sample size and sampling schedule primarily pragmatically based on available resources and experience from adult studies. More recently, the use of model-based clinical trial simula- tions using pharmacometrics methodology has been introduced; this ensures sufficient statistical power while simultaneously minimising the burden on the participating children and the resources used. ${ }^{20}$ Pharmacometrics is a rapidly advancing field, aimed at developing and applying mathematical models to represent physiology, pharmacology and disease progression. Because of the insight pharmacometrics provides into PK-pharmacodynamic relationships, it has been demonstrated to be highly useful in drug development. ${ }^{20,21}$ There is clear regulatory guidance on the expectations for paediatric PK studies which states that paediatric studies should be designed to have at least $80 \%$ power to fulfil defined precision criteria for key PK parameters. ${ }^{22}$ Clinical trial simulations using appropriately adjusted pharmacometric models developed from adult data were used in designing the above-mentioned IMPAACT (International Maternal Pediatric Adolescent AIDS Clinical Trials) sponsored paediatric studies of BDQ (P1108) and DLM (P2005). By evaluating the likelihood of fulfilling these precision criteria for a diverse range of design options and sample sizes, the simulations played an integral part in the design decision-making process for these key paediatric PK studies.

For novel medications not previously used in children, an age de-escalation approach, starting enrolment with a cohort of older children and subsequently moving down in age, has traditionally been used. Information gathered in the oldest children can be added to the existing knowledge from adults to generate more confidence in the 
Table 2 Status of PK and safety data on key re-purposed anti-tuberculosis medications in children and ongoing or planned paediatric studies

\begin{tabular}{|c|c|c|c|}
\hline & Current data in children & Key knowledge gaps & Ongoing or planned studies \\
\hline \multicolumn{4}{|l|}{ LVX } \\
\hline PK & $\begin{array}{l}\text { Data in children with MDR-TB } \\
\text { across all ages }(n=73) \text {, limited } \\
\text { in children aged }<2 \text { years; low } \\
\text { exposures at currently used doses }\end{array}$ & $\begin{array}{l}\text { Data on PK in young children, and } \\
\text { optimal paediatric doses in all } \\
\text { ages }\end{array}$ & \multirow{3}{*}{$\begin{array}{l}\text { MDRPK1: PK and safety of second-line } \\
\text { anti-tuberculosis drugs in HIV- } \\
\text { infected and non-infected children } \\
\text { aged 0-14 years with MDR-TB (data } \\
\text { expected on }>100 \text { children on LVX) } \\
\text { MDRPK2: PK and safety of model- } \\
\text { optimised doses of key second-line } \\
\text { anti-tuberculosis drugs in HIV- } \\
\text { infected and non-infected children } \\
\text { aged 0-17 years (data expected on } \\
80-100 \text { children on LVX) }\end{array}$} \\
\hline Safety & $\begin{array}{l}\text { Some data across all ages at } \\
\text { currently used doses; generally } \\
\text { safe and well tolerated at } \\
\text { currently used doses }\end{array}$ & $\begin{array}{l}\text { Data on safety at optimal paediatric } \\
\text { doses in all ages }\end{array}$ & \\
\hline $\begin{array}{l}\text { Drug-drug } \\
\text { interactions }\end{array}$ & $\begin{array}{l}\text { Important interactions with ARVs } \\
\text { not expected; limited data in } \\
\text { children }\end{array}$ & $\begin{array}{l}\text { Confirm no important interactions } \\
\text { with ARVs in HIV-infected } \\
\text { children }\end{array}$ & \\
\hline \multicolumn{4}{|l|}{ MFX } \\
\hline PK & $\begin{array}{l}\text { Data in children with MDR-TB aged } \\
7-14 \text { years }(n=23) \text { showing low } \\
\text { exposures at current doses; no } \\
\text { data for ages }<7 \text { years }\end{array}$ & $\begin{array}{l}\text { Data on PK in children aged }<7 \\
\text { years, and optimal paediatric } \\
\text { doses in all ages }\end{array}$ & \multirow{3}{*}{$\begin{array}{l}\text { MDRPK1: PK and safety of second-line } \\
\text { anti-tuberculosis drugs in HIV- } \\
\text { infected and non-infected children } \\
\text { aged 0-14 years with MDR-TB (data } \\
\text { expected on } n=40 \text { on MFX) } \\
\text { MDRPK2: PK and safety of model- } \\
\text { optimised doses of key second-line } \\
\text { anti-tuberculosis drugs in HIV- } \\
\text { infected and non-infected children } \\
\text { aged 0-17 years (data expected on } n \\
=80-100 \text { on MFX) }\end{array}$} \\
\hline Safety & $\begin{array}{l}\text { Data in children with MDR-TB aged } \\
7-14 \text { years }(n=23) \text {, safe at } \\
\text { current doses; no data for ages } \\
<7 \text { years }\end{array}$ & $\begin{array}{l}\text { Data on safety at optimal paediatric } \\
\text { doses in all ages }\end{array}$ & \\
\hline $\begin{array}{l}\text { Drug-drug } \\
\text { interactions }\end{array}$ & $\begin{array}{l}\text { Some evidence for possible } \\
\text { interactions with ARVs; limited } \\
\text { data in children }\end{array}$ & $\begin{array}{l}\text { Data on interactions with ARVs in } \\
\text { HIV-infected children }\end{array}$ & \\
\hline \multicolumn{4}{|l|}{ LZD } \\
\hline PK & $\begin{array}{l}\text { Data in children with non- } \\
\text { tuberculous infections; no } \\
\text { published data in children with } \\
\text { TB }\end{array}$ & $\begin{array}{l}\text { Data on PK and optimal paediatric } \\
\text { doses for anti-tuberculosis } \\
\text { treatment in all ages }\end{array}$ & \multirow{3}{*}{$\begin{array}{l}\text { MDRPK 1: PK and safety of second-line } \\
\text { anti-tuberculosis drugs in HIV- } \\
\text { infected and non-infected children } \\
\text { aged } 0-14 \text { years with MDR-TB (data } \\
\text { expected on }<10 \text { on LZD) } \\
\text { MDRPK2: PK and safety of model- } \\
\text { optimised doses of key second-line } \\
\text { anti-tuberculosis drugs in HIV- } \\
\text { infected and non-infected children } \\
\text { aged } 0-17 \text { years (data expected on } \\
\text { LZD PK in } n=80-100 \text { children, } \\
\text { long-term safety in } 10-20 \text { ) }\end{array}$} \\
\hline Safety & $\begin{array}{l}\text { Limited data in children treated for } \\
\text { long courses ( }>28 \text { days) for } \\
\text { MDR-TB }\end{array}$ & $\begin{array}{l}\text { Data on safety at current and } \\
\text { optimal paediatric doses used } \\
\text { long-term for anti-tuberculosis } \\
\text { treatment }\end{array}$ & \\
\hline $\begin{array}{l}\text { Drug-drug } \\
\text { interactions }\end{array}$ & $\begin{array}{l}\text { Important interactions not } \\
\text { expected }\end{array}$ & $\begin{array}{l}\text { Data on overlapping toxicity with } \\
\text { ARVs in HIV-infected children }\end{array}$ & \\
\hline \multicolumn{4}{|l|}{ CFZ } \\
\hline PK & No data in children & $\begin{array}{l}\text { Data on PK and optimal paediatric } \\
\text { doses for anti-tuberculosis } \\
\text { treatment in all ages }\end{array}$ & \multirow[t]{3}{*}{$\begin{array}{l}\text { No planned trials } \\
\text { Small amount of opportunistic PK data } \\
\text { possible from MDRPK } 1 \text { and MDRPK2 }\end{array}$} \\
\hline Safety & $\begin{array}{l}\text { Some experience in children } \\
\text { treated for leprosy }\end{array}$ & $\begin{array}{l}\text { Data on safety at optimal paediatric } \\
\text { doses; safety data when } \\
\text { combined with other QT } \\
\text { prolonging anti-tuberculosis } \\
\text { drugs }\end{array}$ & \\
\hline $\begin{array}{l}\text { Drug-drug } \\
\text { interactions }\end{array}$ & $\begin{array}{l}\text { Interactions possible with ARVs, } \\
\text { but limited data in adults or } \\
\text { children }\end{array}$ & $\begin{array}{l}\text { Data on interactions with ARVs in } \\
\text { adults and children }\end{array}$ & \\
\hline
\end{tabular}

PK = pharmacokinetic; LVX = levofloxacin; MDR-TB = multidrug-resistant tuberculosis; $A R V=$ antiretroviral; MFX = moxifloxacin; HIV = human immunodeficiency virus; $L Z D=$ linezolid; CFZ = clofazimine.

prediction of doses to be tested in the next, younger cohort. A model-based approach leveraging data from adults and older children may provide the best chance of selecting adequate doses for further study. ${ }^{23}$ The age de-escalation approach, however, is very time consuming and cumbersome, with many interim trial stoppages for analysis and dose adjustment, and is not a formal requirement for paediatric trials by stringent regulatory authorities. Modified approaches, such as enrolling children aged $>3$ years in parallel, or using single-dose followed by multipledose trials in all ages concomitantly, have been proposed and are being considered. ${ }^{24}$
Historically, a lack of capacity to implement PK studies in children with MDR-TB has been a limitation to efficient anti-tuberculosis medication evaluation in children. Until recently there was no support for or recognition of the need for such studies, and high MDR-TB burden settings frequently lacked sufficient clinical, research or regulatory capacity for them. This situation is now rapidly evolving, with much needed clinical trial capacity being built, partly due to the opening of the paediatric trials sponsored by Otsuka (Tokyo, Japan) and Janssen (Beerse, Belgium). Furthermore, the IMPAACT network is beginning to leverage its existing, 
Table 3 Current status of paediatric formulation development for novel and key repurposed anti-tuberculosis medications for multidrug-resistant tuberculosis treatment

\begin{tabular}{|c|c|c|}
\hline & Adult formulation & Paediatric formulation \\
\hline Bedaquiline & $100 \mathrm{mg}$ unscored tablets & $\begin{array}{l}\text { Dispersible paediatric tablets developed by Janssen (Beerse, Belgium) } \\
\text { for C } 211 \text { trial }\end{array}$ \\
\hline Delamanid & $50 \mathrm{mg}$ unscored tablets & $\begin{array}{l}\text { Dispersible paediatric tablets developed by Otsuka (Tokyo, Japan) for } \\
232 / 233 \text { trials }\end{array}$ \\
\hline Pretomanid & $100 \mathrm{mg}, 200 \mathrm{mg}$ tablets (trial formulations) & $\begin{array}{l}\text { Dispersible paediatric tablets developed by Dr Reddy's Laboratories } \\
\text { (Hyderabad, India), TB Alliance (Geneva, Switzerland) }\end{array}$ \\
\hline Levofloxacin & $250 \mathrm{mg}$ tablets & $\begin{array}{l}\text { Paediatric suspension exits, but not widely available and not preferred } \\
\text { formulation; dispersible tablets developed by Macleods (Mumbai, } \\
\text { India) for TB-CHAMP trial }\end{array}$ \\
\hline Moxifloxacin & $400 \mathrm{mg}$ tablets & $\begin{array}{l}\text { Gummy formulation being developed by Luna Innovations (Roanoke, } \\
\text { VA, USA) }\end{array}$ \\
\hline Linezolid & $600 \mathrm{mg}$ tablets & $\begin{array}{l}\text { Paediatric suspension exists, but prohibitively expensive and not widely } \\
\text { available }\end{array}$ \\
\hline Clofazimine & $50 \mathrm{mg}$ and $100 \mathrm{mg}$ gel capsules & Gummy formulation being developed by Luna Innovations \\
\hline
\end{tabular}

TB-CHAMP = Tuberculosis CHild and Adolescent Multidrug-resistant Preventive.

experienced network of trial sites, which to date have been more focused on HIV, to study paediatric TB and MDR-TB. These efforts, with continued investment of resources, are important to ensure timely access to children of advances in MDR-TB treatment and prevention, and to support increased international collaboration and advocacy.

\section{CURRENT STATE OF KNOWLEDGE, GAPS AND PLANNED OR ONGOING PAEDIATRIC STUDIES}

The landscape of trials evaluating novel medications and regimens in adults with MDR-TB is rapidly evolving. To ensure that children will be able to benefit from MDR-TB regimens found to be efficacious and/or safer in adult trials, paediatric PK and safety studies should focus on the anti-tuberculosis drugs that are being prioritised in adult studies and that are likely to play key roles in future TB regimens. ${ }^{25}$ An examination of ongoing or planned trials in adults with MDR-TB shows that the following novel and repurposed anti-tuberculosis medications are key components of many MDR-TB treatment regimens under evaluation: BDQ, DLM, PTM, MFX, LVX, CFZ and LZD. ${ }^{26}$ This group of drugs should therefore be the focus of future paediatric studies.

Ensuring the development and availability of childfriendly formulations is another key consideration. Child-friendly characteristics include small tablet/ capsule size and strength (in mg), ability to be mixed with juice or water, measurability even at very small doses, and flavour/palatability. The lack of many of these characteristics in currently available formulations creates the need for imprecise manipulations such as splitting or crushing adult tablets, dissolving them in water or mixing them with food. This impairs accurate dosing, particularly in the youngest children, introduces complexity in administration for parents and health care workers, reduces medication palatability, and may affect bioavailability in unknown ways. ${ }^{27,28}$ These myriad effects have the potential to adversely influence adherence, which is vitally important for ensuring optimal treatment outcomes. ${ }^{29,30}$ The acceptability of formulations for children and their care givers must be considered and should be formally evaluated in studies of antituberculosis drugs. Novel approaches, such as the development of gummy formulations, are being explored and deserve consideration. ${ }^{31}$

Specific PK characteristics of anti-tuberculosis medications in children have been reviewed elsewhere, and such a discussion is beyond the scope of this article. ${ }^{32}$ We summarise below the current state of paediatric knowledge and key gaps, and ongoing or planned trials for priority anti-tuberculosis medications for MDR-TB (in Tables 1 and 2). Much of the PK and safety data described, other than from the multicentre trials, are from a single site in South Africa. Data from diverse settings and populations are needed to better account for pharmacogenetic and other potential differences in PK and safety of these medications. Table 3 shows the current status of paediatric formulation development for these same medications. ${ }^{31}$ It should be noted that delays in studying these medications and developing paediatric formulations are in part related to regulatory and economic barriers. A detailed consideration of these issues is beyond the scope of this review, but they have been discussed elsewhere. ${ }^{24}$ Although the need for improved treatment among affected children is great, the market is small. Innovative solutions will be needed to accelerate this important work to ensure equitable access to anti-tuberculosis treatment in children.

\section{Bedaquiline}

The opening of paediatric BDQ trials has been much delayed. Despite global roll-out and increasing access to BDQ for adults, even in routine care settings, ${ }^{33}$ to date there are no PK data in children. Two paediatric trials will begin to fill this gap. The Janssen-sponsored 
C211 paediatric trial (NCT02354014) is a Phase II study of BDQ PK and safety in combination with an optimised background regimen (OBR) in children with MDR-TB; only non-HIV-infected children are included. Enrolment in this age de-escalation trial began in 2016. The P1108 trial (NCT02906007) sponsored by the US National Institute of Allergy and Infectious Disease (NIAID; Bethesda, MD, USA) Infant Maternal Pediatric Adolescent AIDS Clinical Trial (IMPAACT) network will also evaluate the PK and safety of BDQ in combination with OBR in both HIV-infected and noninfected children with MDR-TB; the trial is expected to open in early 2017. Janssen has developed a dispersible paediatric BDQ formulation, which will be evaluated in their trial; however, this formulation may not be available in the field for some time. The IMPAACT network has sponsored a trial comparing the bioavailability of whole and dissolved BDQ (TASK-002, NCT03032367), which will inform the use of the dissolved adult formulation for children who cannot swallow whole tablets. It is also conceivable that local economic or regulatory barriers will limit the widespread availability of the paediatric dispersible tablets for some time. Bioavailability data on crushed adult tablets will help bridge the expected time gap when data on BDQ dosing in children are available but the BDQ paediatric formulation is not.

\section{Delamanid}

The Otsuka-sponsored Phase I (242-12-232, NCT01856634) and Phase II (242-12-233, NCT01859923) paediatric DLM trials opened in 2013. DLM PK data from Group 1 (ages 12-17 years, adult dose) and Group 2 (ages 6-11 years, half adult dose) of these age de-escalation trials showed that exposure in children was within the range seen in adults. This led the World Health Organization (WHO) to recommend doses and indications for DLM use for children aged 6-17 years with MDRTB. ${ }^{34}$ PK data from Group 3 (ages 3-5 years) and Group 4 (ages 0-2 years) from this trial are expected in 2017. HIV-infected children were excluded from Groups 1-3, but will be allowed in Group 4. IMPAACT 2005 is a planned trial on DLM PK and safety in both HIV-infected and non-HIV-infected children with MDR-TB to address this gap, and is expected to open in 2017. Otsuka has developed a dispersible, taste-masked paediatric formulation in two strengths, which is being evaluated in Groups 3 and 4 of its paediatric trials, and will also be used for the youngest children (age $<6$ years) in the IMPAACT 2005 study.

\section{Pretomanid}

There are no PTM pharmacokinetic data in children, and no ongoing or immediately planned paediatric trials. This delay is at least in part due to concerns with PTM safety. Testicular toxicity was seen in some animal models, as it has been with other nitroimidazole compounds such as metronidazole; ${ }^{35}$ however, the clinical significance in humans is not entirely clear. Moreover, the Shortening Treatment by Advancing Novel Drugs (STAND) trial evaluating a regimen comprising PTM-MFX-pyrazinamide for both drug-susceptible and MDR-TB in adults (NCT02342886) was temporarily put on hold due to hepatotoxicity in the experimental arm; the trial has been cleared by the Data Safety Monitoring Committee to re-start. ${ }^{26}$ A substudy within the STAND trial aims to evaluate the presence of any testicular toxicity. ${ }^{36}$ Particularly given emerging evidence on the success of PTM-containing regimens in adult Phase II and III trials, ${ }^{37,38}$ the paediatric trials should start as soon as safety concerns have been sufficiently alleviated. A prototype paediatric formulation of PTM has been developed. ${ }^{39}$

\section{Moxifloxacin}

The paediatric development of MFX for non-tuberculosis bacterial indications was limited, at least partly due to its bitterness and poor palatability. The only published PK data are for 23 children aged 7-15 years treated for MDR-TB, ${ }^{14}$ from a US National Institutes of Health (NIH; Bethesda, MD, USA) funded observational PK study in Cape Town, South Africa (MDRPK1, Pharmacokinetics and toxicity of second-line anti-tuberculosis drugs in HIV-infected and -uninfected children). This study showed low MFX exposures in children who received the recommended paediatric doses $(10 \mathrm{mg} / \mathrm{kg})$ relative to exposures seen in adults after a $400 \mathrm{mg}$ dose. ${ }^{14} \mathrm{PK}$ data in children aged $<7$ years and analysis to determine more optimal doses across all ages are thus urgently needed. An NIH-funded study of the PKs of model-based doses of key second-line TB medications in children routinely treated for MDRTB in Cape Town opened in 2015, and should address some of these knowledge gaps (MDRPK2, Optimizing and operationalizing pediatric drug-resistant tuberculosis treatment). There is no child-friendly formulation of MFX, and the existing adult formulation is an exceedingly large tablet, difficult to split and bitter when crushed, making accurate and tolerable dosing in children problematic. A tastemasked dispersible tablet with lower strength is needed for reliable paediatric dosing.

\section{Levofloxacin}

A growing body of observations in children receiving LVX for MDR-TB has shown that currently recommended paediatric doses for MDR-TB (15-20 mg/kg once daily) result in exposures well below those in adults receiving the most frequently used dose of 750 mg once daily. ${ }^{40,41}$ Optimal paediatric doses of LVX, and safety at those doses, remain to be established; the MDRPK2 study aspires to address this gap. 
Although an LVX suspension does exist, it is not available in most high TB burden settings, and suspensions are not preferred either by health systems, because of challenges with storage and shelf-life, or by patients and care givers. ${ }^{42}$ A $100 \mathrm{mg}$ dispersible LVX tablet (Macleods Pharmaceuticals Ltd, Mumbai, India) has been developed for a paediatric trial of LVX for MDR-TB preventive therapy (Tuberculosis CHild and Adolescent Multidrug-resistant Preventive [TB-CHAMP] therapy trial, ISRCTN92634082), and could potentially become available more widely after the trial has been completed. The PK of this formulation is being evaluated in a lead-in phase of that trial.

\section{Clofazimine}

Although CFZ has been used for decades for the treatment of leprosy in children, there are no published, or to our knowledge unpublished, paediatric PK data available. There are no ongoing or planned trials of CFZ PKs in children with TB. Limited data from a few patients in the MDRPK1 study are available, and there may be the possibility to opportunistically study CFZ in the MDRPK2 study as the routine use of CFZ becomes more widespread in response to new guidelines from the WHO. ${ }^{43} \mathrm{CFZ}$ is only available in $50 \mathrm{mg}$ and $100 \mathrm{mg}$ gel capsules. These are not flexible formulations, cannot be split or opened, and may be challenging for young children to swallow. Given the potentially important role in future TB treatment regimens, CFZ PK, safety and acceptability studies in children, and the development of a child-friendly formulation, are therefore a priority.

\section{Linezolid}

As LZD has been used for the treatment of resistant Gram-positive bacterial infections, there are data on its PK and safety in children with non-tuberculous infections for short-term use $\left(<28\right.$ days). ${ }^{44}$ However, there are no published PK data in children with TB, and the doses needed in children to approximate exposures in adults after the $600 \mathrm{mg}$ once daily dose used for TB are not yet known. ${ }^{45}$ The MDRPK2 study is aimed at evaluating LZD PKs in children with MDR-TB; combined with data from MDRPK1, this will provide much-needed information on optimal and safe LZD paediatric dosing for TB treatment. An LZD suspension exists, but its use for long courses for MDR-TB treatment is cost-prohibitive, and access in many settings is limited. Manipulation of the adult $600 \mathrm{mg}$ tablet for paediatric dosing may be problematic and is not a long-term solution, due to the large tablet size and strength, difficulty in suspending and lack of data on impact on bioavailability. A reasonably priced flexible solid-oral dosage formulation for children is needed.

\section{IMPLICATIONS FOR AN EFFICACY TRIAL IN CHILDREN WITH MDR-TB}

There is a critical need for shorter duration, injectable-sparing, safe, acceptable and efficacious regimens for children, and there is consensus that an efficacy trial is also urgently needed. A clearer understanding of the safety and appropriate dosing of medications to be included in a Phase III paediatric MDR-TB efficacy trial is required. The lack of comprehensive data or knowledge of perfect doses should not be used to delay such a trial going forward, in which dosing based on the best available evidence should be used. Data from ongoing studies are expected to inform paediatric dosing of MFX, LVX, LZD and DLM in the near future. The lack of planned paediatric studies of CFZ is worrying. Although it is already recommended and being used in the field for MDR-TB treatment in children, and it is reassuring that there is substantial experience supporting its safety in children treated for leprosy, pharmacokinetic studies of CFZ in children with MDR-TB should be prioritised. The lack of paediatric-specific data on BDQ and PTM will likely preclude their use in a paediatric efficacy trial in the immediate future.

It is also worth noting that existing paediatric PK data clearly add support for an efficacy trial in children. The FQs, with their potent bactericidal activity, are considered the most important component of existing MDR-TB regimens. Alarmingly, published data have shown that children with MDR-TB treated with currently recommended doses of ofloxacin, LVX and MFX have plasma FQ exposures well below those in adults. ${ }^{14,40,41}$ However, despite these low exposures, treatment outcomes in children are much better than in adults with MDRTB, with $80-90 \%$ of children successfully treated globally compared to $50 \%$ of adults in most highburden settings. ${ }^{46,47}$ Low drug exposures in children, combined with already improved outcomes compared to adults, clearly call into question the assumption that children have a similar disease progression and response to treatment to that of adults; these factors combined provide a clear justification for an efficacy trial in children. Improved paediatric dosing of these medications is still important in promoting optimal outcomes with a shortened regimen in such a trial.

\section{CONCLUSION}

Although much remains to be done, there has been substantial progress in recent years in studying and understanding second-line and novel anti-tuberculosis medications in children. Precisely because they differ from adults with MDR-TB, children represent a group that is uniquely poised to benefit from shorter, 
less toxic and less burdensome treatments for MDRTB. It is imperative that the rigorous investigation of such treatments continues and accelerates. Expanding global clinical trial capacity for MDR-TB in children, and closer collaboration between researchers, industry, funders and affected communities, will be required to ensure that the progress made thus far is not lost, and that children with MDR-TB continue to benefit.

\section{Acknowledgements}

The authors thank RESIST-TB, IMPAACT (International Maternal Pediatric Adolescent AIDS Clinical Trials; Bethesda, MD), Vital Strategies (New York, NY), and New Ventures (Yale University, New Haven, CT) for hosting the Pediatric Multidrug Resistant Tuberculosis Clinical Trials Landscape Meeting in Arlington, VA, USA on 17 June 2016, which was the impetus for this work.

EMS has received funding from the Swedish Research Council, Stockholm, Sweden (grant number 521-2011-3442). EDW has received funding from the NIH/Division of AIDS (IMPAACT Group Leadership Award) under award number UM1 AI068632, the Johns Hopkins University Center for AIDS Research (Baltimore, MD, USA) under award number P30AI094189, the Pearl M Stetler Award for Women Physicians, and the NIH Clinical Pharmacology T32 GM066691-11. HSS is supported by the South African National Research Foundation, Pretoria, South Africa.

AGP, EMS, and EDW are on the protocol team for the IMPAACT 2005 trial; ACH, HSS and EMS are on the IMPAACT P1108 protocol team; ACH, AGP, and HSS are involved as a research site in the Otsuka 232/233 trials, and lead the MDRPK1 and MDRPK2 studies.

Conflicts of interest: all authors report no financial conflicts of interest.

\section{References}

1 Jenkins $\mathrm{H}$ E, Tolman A W, Yuen C M, et al. Incidence of multidrug-resistant tuberculosis disease in children: systematic review and global estimates. Lancet 2014; 383: 1572-1579.

2 Dodd P J, Sismanidis C, Seddon J A. Global burden of drugresistant tuberculosis in children: a mathematical modelling study. Lancet Infect Dis 2016; 16: 1193-1201.

3 McAnaw S E, Hesseling A C, Seddon J A, et al. Pediatric multidrug-resistant tuberculosis clinical trials: challenges and opportunities. Int J Infect Dis 2017; 56: 194-199.

4 Dunne J, Rodriguez W J, Murphy M D, et al. Extrapolation of adult data and other data in pediatric drug-development programs. Pediatrics 2011; 128: e1242-1249.

5 Nachman S, Ahmed A, Amanullah F, et al. Towards early inclusion of children in tuberculosis drugs trials: a consensus statement. Lancet Infect Dis 2015; 15: 711-720.

6 Donald P R, Ahmed A, Burman W J, et al. Requirements for the clinical evaluation of new anti-tuberculosis agents in children. Int J Tuberc Lung Dis 2013; 17: 794-799.

7 West G B. The importance of quantitative systemic thinking in medicine. Lancet 2012; 379: 1551-1559.

8 Anderson B J, Holford N H G. Understanding dosing: children are small adults, neonates are immature children. Arch Dis Child 2013; 98: 737-744.

9 Kearns G L, Abdel-Rahman S M, Alander S W, Blowey D L, Leeder J S, Kauffman R E. Developmental pharmacologydrug disposition, action, and therapy in infants and children. $\mathrm{N}$ Engl J Med 2003; 349: 1157-1167.

10 Drobac P C, Mukherjee J S, Joseph J K, et al. Community-based therapy for children with multidrug-resistant tuberculosis. Pediatrics 2006; 117: 2022-2029.
11 Schaaf H S, Gie RP, Kennedy M, Beyers N, Hesseling P B, Donald P R. Evaluation of young children in contact with adult multidrug-resistant pulmonary tuberculosis: a 30-month follow-up. Pediatrics 2002; 109: 765-771.

12 Schaaf H S, Thee S, van der Laan L, Hesseling A C, Garcia-Prats A J. Adverse effects of oral second-line anti-tuberculosis drugs in children. Expert Opin Drug Saf 2016; 15: 1369-1381.

13 Garcia-Prats A J, Draper H R, Thee S, et al. Pharmacokinetics and safety of ofloxacin in children with drug-resistant tuberculosis. Antimicrob Agents Chemother 2015; 59: 60736079.

14 Thee S, Garcia-Prats A J, Draper H R, et al. Pharmacokinetics and safety of moxifloxacin in children with multidrug-resistant tuberculosis. Clin Infect Dis 2015; 60: 549-556.

15 Blake K V, Saint-Raymond A, Zaccaria C, Domergue F, Pelle B, Slattery J. Enhanced paediatric pharmacovigilance at the European Medicines Agency: a novel query applied to adverse drug reaction reports. Paediatr Drugs 2016; 18: 55-63.

16 Blake K V, Zaccaria C, Domergue F, La Mache E, SaintRaymond A, Hidalgo-Simon A. Comparison between paediatric and adult suspected adverse drug reactions reported to the European medicines agency: implications for pharmacovigilance. Paediatr Drugs 2014; 16: 309-319.

17 Burkhardt J E, Walterspiel J N, Schaad U B. Quinolone arthropathy in animals versus children. Clin Infect Dis 1997; 25: 1196-1204.

18 Bradley J S, Kauffman R E, Balis D A, et al. Assessment of musculoskeletal toxicity 5 years after therapy with levofloxacin. Pediatrics 2014; 134: e146-e153.

19 Pineiro-Carrero V M, Pineiro E O. Liver. Pediatrics 2004; 113 (Suppl): S1097-S1106.

20 Vinks A A, Emoto C, Fukuda T. Modeling and simulation in pediatric drug therapy: application of pharmacometrics to define the right dose for children. Clin Pharmacol Ther 2015; 98: 298-308.

21 Williams P, Ette E. Pharmacometrics: impacting drug development and pharmacotherapy. In: Ette E, Williams P, eds. Pharmacometrics: the science of quantitative pharmacology. Hoboken, NJ, USA: 2007: pp 1-21.

22 Wang Y, Jadhav P R, Lala M, Gobburu J V. Clarification on precision criteria to derive sample size when designing pediatric pharmacokinetic studies. J Clin Pharmacol 2012; 52: 16011606.

23 Cella M, Gorter de Vries F, Burger D, Danhof M, Della Pasqua O. A model-based approach to dose selection in early pediatric development. Clin Pharmacol Ther 2010; 87: 294-302.

24 Murray S, McKenna L, Pelfrene E, Botgros R. Accelerating clinical drug development for children with tuberculosis. Int J Tuberc Lung Dis 2015; 19 (Suppl 1): S69-S74.

25 RESIST-TB. DR-TB Clinical Trials Progress Report. Cambridge, MA, USA: RESIST-TB, 2017. http://www. resisttb.org/?page_id=1602. Accessed September 2017.

26 Lessem E. The tuberculosis treatment pipeline: activity, but no answers. New York, NY, USA: Treatment Action Group (TAG), 2016. http://www.pipelinereport.org/2016/tb-treatment. Accessed September 2017.

27 Furin J, Mafukidze A, Brigden G, et al. A bitter pill to swallow: the need for better medications for drug-resistant tuberculosis in children. Int J Tuberc Lung Dis 2015; 19 (Suppl 1): 55-60.

28 Taneja R, Garcia-Prats A J, Furin J, Maheshwari H K. Paediatric formulations of second-line anti-tuberculosis medications: challenges and considerations. Int J Tuberc Lung Dis 2015; 19 (Suppl 1): S61-S68.

29 Baguley D, Lim E, Bevan A, Pallet A, Faust S N. Prescribing for children-taste and palatability affect adherence to antibiotics: a review. Arch Dis Child 2012; 97: 293-297.

30 Dagan R, Shvartzman P, Liss Z. Variation in acceptance of common oral antibiotic suspensions. Pediatr Infect Dis J 1994; 13: 686-690. 
31 Treatment Action Group. 2017 Pipeline Report: HIV, TB \& HCV. Drugs, diagnostics, vaccines, preventive technologies, cure research, and immune-based and gene therapies in development. New York, NY, USA: TAG, 2017. http://www. treatmentactiongroup.org/pipeline-report/2017. Accessed September 2017.

32 Schaaf H S, Garcia-Prats A J, Donald P R. Anti-tuberculosis drugs in children. Clin Pharmacol Ther 2015; 98: 252-265.

33 Guglielmetti L, Hewison C, Avaliani Z, et al. Examples of bedaquiline introduction for the management of multidrugresistant tuberculosis in five countries. Int J Tuberc Lung Dis 2017; 21: 167-174.

34 World Health Organization. The use of delamanid in the treatment of multidrug-resistant tuberculosis in children and adolescents: interim policy guidance. WHO/HTM/TB/2016.14. Geneva, Switzerland: WHO, 2016. http://who.int/tb/ publications/Delamanid_interim_policy/en/. Accessed September 2017.

35 McClain R M, Downing J C, Edgcomb J E. Effect of metronidazole on fertility and testicular function in male rats. Fundam Appl Toxicol 1989; 12: 386-396.

36 ClinicalTrials.gov. Shortening treatment by advancing novel drugs (STAND). https://clinicaltrials.gov/ct2/show/NCT02342886. Bethesda, MD, USA: US National Institutes of Health, 2014. Accessed September 2017.

37 Dawson R, Harris K, Conradie A, et al. Efficacy of bedaquiline, pretomanid, moxifloxacin and PZA (BPaMZ) against DS- \& MDR-TB. Conference on Retroviruses and Opportunistic Infections (CROI), 13-16 February 2017, Seattle, WA, USA. [Abstract no: 724LB]

38 Conradie F, Diacon A H, Everitt D, et al. The Nix-TB trial of pretomanid, bedaquiline and linezolid to treat XDR-TB. Conference on Retroviruses and Opportunistic Infections (CROI), 13-16 February 2017, Seattle, WA, USA.

39 Dalsania S, Kumar N V, Singh P P, Kodipyaka R, Taneja R. Preomanid (PA-824) dispersible tablets: a step forward to combat paedaitric tuberculosis in developing nations. American Association of Pharmaceutical Scientists (AAPS) 2016 Annual Meeting, 17 November 2016, Denver, CO, USA. [Abstract 01R0900].

40 Thee S, Garcia-Prats A J, McIlleron H M, et al. Pharmacokinetics of ofloxacin and levofloxacin for prevention and treatment of multidrug-resistant tuberculosis in children. Antimicrob Agents Chemother 2014; 58: 2948-2951.

41 Mase S R, Jereb J A, Gonzalez D, et al. Pharmacokinetics and dosing of levofloxacin in children treated for active or latent multidrug-resistant tuberculosis, Federated States of Micronesia and Republic of the Marshall Islands. Pediatr Infect Dis J 2016; 35: 414-421.

42 Nahirya-Ntege P, Cook A, Vhembo T, et al. Young HIVinfected children and their adult caregivers prefer tablets to syrup antiretroviral medications in Africa. PLOS ONE 2012; 7: e36186.

43 World Health Organization. WHO treatment guidelines for drug-resistant tuberculosis: 2016 update. WHO/HTM/TB/ 2016.04. Geneva, Switzerland: WHO, 2016.

44 Jungbluth G L, Welshman I R, Hopkins N K. Linezolid pharmacokinetics in pediatric patients: an overview. Pediatr Infect Dis J 2003; 22 (Suppl): S153-S157.

45 Garcia-Prats A J, Rose P C, Hesseling A C, Schaaf H S. Linezolid for the treatment of drug-resistant tuberculosis in children: A review and recommendations. Tuberculosis (Edinb) 2014; 94: 93-104.

46 Ettehad D, Schaaf H S, Seddon J A, Cooke G S, Ford N. Treatment outcomes for children with multidrug-resistant tuberculosis: a systematic review and meta-analysis. Lancet Infect Dis 2012; 12: 449-456.

47 Seddon J A, Hesseling A C, Godfrey-Faussett P, Schaaf H S. High treatment success in children treated for multidrugresistant tuberculosis: an observational cohort study. Thorax 2014; 69: 458-464. 
Après des décennies de négligence, nous disposons finalement de données relatives à la posologie appropriée et sûre des principaux médicaments antituberculeux de deuxième ligne utilisés pour le traitement de la tuberculose multirésistante (TB-MDR) des enfants, dont la lévofloxacine (LVX), la moxifloxacine (MFX), le linézolide (LZD) et le délamanide (DLM). Mais on manque toujours de données relatives à certains médicaments nouveaux et recyclés, incluant la bédaquiline (BDQ), le prétomanide (PTM) et la clofazimine (CFZ). Nous revoyons le statut des études de pharmacocinétique (PK) et de sécurité des principaux médicaments antituberculeux chez les enfants atteints de TB-MDR, identifions les lacunes prioritaires en matière de connaissances et notons le travail en cours pour affronter ces lacunes, dans le contexte de la planification d'un essai d'efficacité chez des enfants atteints de TB-MDR. Il y a un consensus international sur le fait qu'un essai d'efficacité d'un traitement de TB-MDR nouveau, exclusivement oral et raccourci chez des enfants est à la fois nécessaire et faisable. Les médicaments antituberculeux de deuxième ligne principaux, nouveaux et recyclés, incluent la BDQ, le DLM, le PTM, la MFX, le LVX, la CFZ et le LZD. Les données, en rapide expansion, de PK et de sécurité relatives à ces médicaments chez les enfants atteints de TB-MDR, émanant d'études qui sont en cours, achevées ou prévues, seront cruciales pour soutenir un tel essai d'efficacité. Un engagement à affronter les lacunes résiduelles de connaissances, l'élaboration de formules des principaux médicaments adaptées aux enfants, l'amélioration de la conception des études pédiatriques de PK et de sécurité et le développement d'une capacité internationale de réalisation d'essais parmi les enfants atteints de TB-MDR sont des priorités majeures.

\section{RES U MEN}

Tras decenios de negligencia, por fin se han publicado datos sobre la posología apropiada y segura de los principales fármacos antituberculosos de segunda línea en el tratamiento de la tuberculosis multirresistente (TBMDR) de los niños, que incluyen el levofloxacino (LVX), el moxifloxacino (MFX), el linezolid (LZD) y el delamanid (DLM). Aún faltan datos muy necesarios sobre algunos fármacos nuevos y fármacos a los cuales se ha asignado una nueva utilización, como la bedaquilina (BDQ), el pretomanid (PTM) y la clofazimina (CFZ). En el presente artículo se analiza la situación de los estudios farmacocinéticos (PK) y de toxicidad de los medicamentos antituberculosos en los niños con TBMDR, se definen las prioridades en las carencias de conocimientos y se mencionan los trabajos en curso que abordan estas lagunas en el contexto de la planificación de un ensayo clínico de eficacia en niños con TB-MDR. Existe una opinión internacional unánime sobre la necesidad y la factibilidad de un ensayo clínico de eficacia de un nuevo tratamiento de la TB-MDR pediátrica que sea corto y de administración oral exclusiva. Entre los fármacos antituberculosos de segunda línea nuevos y con nuevas indicaciones se cuentan los siguientes: BDQ, DLM, PTM, MFX, LVX, CFZ y LZD. Los numerosos datos PK y de toxicidad que surgen en la actualidad sobre la utilización de estos fármacos en la TB-MDR de los niños, provenientes de estudios en curso, estudios finalizados o ensayos planificados serán esenciales para fundamentar el ensayo clínico de eficacia antes mencionado. Otras prioridades importantes se relacionan con el estudio de los vacíos que persisten en los conocimientos, el desarrollo de presentaciones de los principales fármacos que sean adecuadas para los niños, el perfeccionamiento del diseño de los estudios PK y de toxicidad en pediatría y el refuerzo de la capacidad para realizar ensayos internacionales en los niños con diagnóstico de TB-MDR. 